\title{
Response in growth and yield of the local palu shallot (Allium ascalonicumL. Var. Aggregatum) to the direction and building form of the planting beds
}

\begin{abstract}
Shallot (Allium ascalonicumL.) is one of the economically important types of tuber vegetables and is widely consumed as a food seasoning. In addition, shallots are also used as ingredients of certain medicines. Development of Palu local shallot farming is mostly done on dry land, both on flat and sloping land concessions with the application of improvised technology.

This research uses a Split Plot Design. The main plot is the direction of the beds (A) consisting of 2 (two) levels, namely: (A1) = The beds are made in the direction of the slope of the land and $(\mathrm{A} 2)=$ the beds are made to cut the direction of the slope of the land. The subplot is the Shape of the Bed (B) consisting of two levels, namely: (B1) = Inner bed and $(B 2)=$ High bed. Each treatment was repeated three times, so that overall there were $2 x$ $2 \times 3=12$ trial plots. To determine the type of treatment in each trial plot, randomization was previously carried out. Randomization was carried out in stages, namely: the first stage randomized the location of the Main Plots, then continued the second stage by randomizing the Plots in each Main Plot.

The results of this study indicate that there is no real interaction between the treatment of the beds and the shape of the beds on the growth and yield of Palu's local shallots in Guntarano Village. In general, the treatment of the beds does not significantly affect the growth and yield of Palu local shallots. The shape of the inner beds can give growth and yield of Palu local shallots better than the shape of the raised beds.
\end{abstract}

Volume 4 Issue 2 - 2020

\author{
Ramli,', Sulfina ${ }^{2}$ \\ 'Department of Agriculture, University of Tadulako, Indonesia \\ ${ }^{2}$ Students Department of Agriculture, University of Tadulako, \\ Indonesia
}

Correspondence: Ramli Moh Ali,Department of Agriculture, University of Tadulako, Palu, Indonesia, 94 I I8, Tel 08524 I0 I4 I I7, Email ramlimohali07@gmail.com

Received: April 04, 2020 | Published: April 28, 2020

Keywords: growth, bed, and shallots

\section{Introduction}

Shallot (Allium ascalonicumL.) isone of the economically important types of tuber vegetables and is widely consumed as a food seasoning. In addition, shallots are also used as certain medicinal ingredients. ${ }^{1}$ Shallot bulbs are mostly made up of water. From 100 grams of tubers, the water content alone can reach around $85 \%$. The protein is about $1,5 \%, 0,3 \%$ fat and $9,2 \%$ carbohydrate. $^{2}$

Based on data from the Ministry of Agriculture (2016) it is known that the harvest area of shallots from 2012 is 99,519 hectares and continues to increase from year to year, until 2016 the harvested area has reached 148,434 hectares, but the productivity of shallots in Central Sulawesi is still very low $(3,37-5.31$ tons / ha) compared to national productivity that has reached (9.66-10.22 tons/ha). The yield is still relatively low because the potential yield of shallots in general can reach 10 t/ha. ${ }^{3}$ Specifically, in Central Sulawesi, especially in the Palu Valley which has a dry climate, there is a local shallot which is very suitable as a raw material for making fried shallots, because it has a dense texture, savory taste and has a distinctive aroma, so much favored for cooking spices and as snacks. Thus, the local shallots of Palu including commodities typical of Central Sulawesi which has high competitiveness so that development needs to continue to be pursued. ${ }^{4}$

Development of Palu local shallot farming is mostly done on dry land, both on flat and sloping land conditions with the application of improvised technology, including the technical of making beds that have not considered the aspects of soil and water conservation, but only consider the practical aspects and its ease, especially in water supply, so that crop productivity is low and there is a tendency to decrease from year to year due to decreased soil fertility.

The technique of making beds at the location of the local shallot development center in Palu in Gorontalo Village can be found in various forms, namely beds stretching in the direction of the slope using the form of "inner beds" surrounded by embankments to facilitate water flow into the beds and there are also beds transversely cut in the direction of the slope or in the direction of the contour of the land in the form of "high beds" surrounded by a moat. Thus both the directions and shape of the beds need to be investigated to determine their effect on the growth and yield of Palu's local shallots, because of the two directions and shape of the beds there are differences in the way of water management, including in relation to water management and nutrients for the needs plant during its growth.

Based on these conditions it is deemed necessary to conduct research to determine the effect of the direction and shape of the beds on the growth and yield of local variant shallot plants in Palu in Guntarano Village.

This research aims to study and determine the effect of the direction and form of beds on the growth and yield of local Palu shallot. The results of this research are expected to be a source of information about the technique of making good beds, especially the direction and shape of beds that can provide results for planting shallots. 


\section{Materials and methods}

\section{Location}

The study was conducted in Guntarano Village, Tawaeli District, Palu City, Central Sulawesi, from October 2018 to January 2019.

\section{Research methods}

This research uses a Split Plot Design. The main plot is the direction of the beds (A) consisting of 2 (two) levels, namely: (A1) = The beds are made in the direction of the slope of the land and (A2) $=$ the beds are made to cut the direction of the slope of the land. Plot Child is a Form of Bed (B) consisting of two levels, namely: (B1) = Bed in and $(B 2)=$ Bed high .

Each treatment was repeated three times, so that overall, there were $2 \times 2 \times 3=12$ experimental plots, randomization was previously carried out. Randomization was carried out in stages, namely: the first stage randomized the location of the Main Plots, then continued with the second stage by randomizing the Child Plots in each Main Plot.

The mathematical model of this experiment is as follows:

$$
\begin{aligned}
& Y_{i j}=\mu+K_{k}+A_{i}+€_{i k}+B_{j}+(A B)_{i j}+\sigma_{i j k} \\
& i=(1 ; 2), j=(1 ; 2), k=(1 ; 2 ; 3)
\end{aligned}
$$

Note :

$\mathrm{Y}_{\mathrm{ij}}$ : Observation value due to the influence of the direction of the first-level beds and the shape of the j-

level beds on the k-replicates.

$\mu$ : Common mean or general mean .

$\mathrm{K}_{\mathrm{K}}$ : Effect of groups or replicates all $\mathrm{k}$.

$A_{i}:$ The effect of the direction of the bed $i$.

$€_{\mathrm{ik}}$ : Effect of leftovers for the main plot or residual effect for all directions seedbed stage I in group to $\mathrm{k}$

$B_{j}$ : Effect ofshape beds .

$(A B)_{i j}$ : Influence of the interaction of the direction of the first bed and the shape of the third bed

$\sigma_{i j \mathrm{j}}$ : Influence of residuals for subplots or residual effects due to the influence of the direction of the first

level beds and the effect of the shape of the beds in the k-group.

\section{Research implementation}

\section{Land preparation}

The land that will be used as a research location is cleared first from weeds and other plant residues. Soil cultivation is done two weeks before planting. The soil is cultivated using plows and rake twice as deep as $30 \mathrm{~cm}$. Then made beds in accordance with the treatment with a width of $1,0 \mathrm{~m}$ long $7,0 \mathrm{~m}$ as many as 12 plots. To flatten the surface of the plot hoe and scope are used. Distance seedbed treatment in replay is $1,0 \mathrm{~m}$, while the distance between replications plot is $0,75 \mathrm{~m}$.

\section{Making beds}

Making beds based on the direction of the slope of the land consists of two directions, namely beds in the direction of the slope of the land and beds that cut the direction of the slope of the land. Beds in the same direction as the slope of the land are made in a long way with beds 7,0 across the direction of the slope and are the main plot. Furthermore, the beds in the same direction as the slope of the land are made in two forms, namely beds in the form of "deep beds" surrounded by bunds and beds in the form of "high beds" as high as 25 $\mathrm{cm}$ surrounded by trenches, where these beds are sub-plots.

\section{Planting}

The seeds are planted in a single way and placed perpendicular to the planting hole with the tubers positioned flat on the ground. Planting is done with a spacing of $20 \mathrm{~cm} \times 20 \mathrm{~cm}$, so that in each trial plot there are 175 plants per plant. Once the seeds are planted, watering is done every day by way of putting water into the ditch and embankment to the ground to get water completely or reach field capacity.

\section{Fertilization}

The types of fertilizers applied are urea, SP36 and KCI, each according to the recommended dosage: 200, 200 and $100 \mathrm{~kg}$ per hectare. SP36 and KCI fertilizers were given 1 week after planting (MST), urea was given in stages ie $1 / 2$ given at the age of 1 MST planting and the remaining $1 / 2$ were given at the age of 35 HST. How to administer fertilizers with an array system.

\section{Observation}

To see the effect of the direction and shape of the beds, observations were made on:

i. Number of Leaves (Strands). Observation number of leaves is done by calculates all the leaves that form those perfect in one clump tanama n, performed at 15, 25, 35 and 45 DAP

ii. Leaf Length (cm). Observation of leaf length was carried out by measuring the perfectly formed long-leaf leaves on a clump of plants, measurements were carried out at ages 15, 25, 35 and 45 DAP

iii. The dry weight of the leaves is done by removing the plant from the growing media, cleaning it, then drying it at $80^{\circ} \mathrm{C}$ for 2 times hours or until the dry weight is constant. Observations were made at ages $15,25,35$ and 45 DAP

iv. Total leaf area per plant. The total leaf area per plant at the ages of $15,25,35$ and 45 DAP., Calculated by weighing method (by gravimetry) based on the dry weight of the leaves, with the following formula:

LDs

$\mathrm{LD}=-------------\quad \mathrm{BkDt}$

BkDs

Where:LD $=$ Leaf area per plant $\left(\mathrm{cm}^{2}\right)$

LDs $=$ Area of leaf sample $\left(\mathrm{cm}^{2}\right)$

BkDs $=$ The known dry weight of sample leaves $(\mathrm{g})$

$\mathrm{BkDt}=$ dry weight of total leaves per plant $(\mathrm{g})$

v. Total dry weight of plants. Done by unloading plants from growing media, cleaning, then dried at a temperature of $80^{\circ} \mathrm{C}$ for 2 timeshours or until the dry weight is constant. Observations were made at ages 15, 25, 35 and 45 DAP

vi. Number of tubers per clump (fruit). Observation number of tubers by way of counting all the tubers are formed on each cluster and performed at the time of harvest. 
vii. Weight of dried tuber harvest (g / clump). Observations weights is done by means of weighing tuber per hill after harvest.

viii. Wet tuber yield per hectare $\left(\mathrm{ha}^{-1}\right)$. Done by way of calculating the results of the tile and then converted into the results of wet bulb shallots per hectare.

\section{Data analysis}

Data that have been obtained are analyzed diversity, and if the $\mathrm{F}$ test results indicate that the treatment given has a real effect, then further tests are conducted using the Honestly Significant Difference test (HSD) at the level of confidence $\alpha 0.05$.

\section{Results}

\section{Number of leaves}

The results of variance showed that the interaction of treatment in the direction of the beds and the shape of the beds did not significantly affect the number of local shallots in Palu, while the shape of the beds had a significant effect on the number and age of $15,25,35$ and 45 DAP, but at the age of 15 DAP. No significant effect on the number of Palu local shallots.

HSD analysis results $\alpha 0,05$ (Table 1 ) shows that the shape of beds in producing the highest number of leaves and significantly different from the shape of high beds at the age of 15, 25, 35 and 45 DAP.

Table I Average number of leaves age 15, 25, 35 and 45 in the treatment bed shape

\begin{tabular}{llll}
\hline \multirow{2}{*}{ Bed Shape } & \multicolumn{3}{l}{ Age (DAP) } \\
\cline { 2 - 4 } & $\mathbf{2 5}$ & $\mathbf{3 5}$ & $\mathbf{4 5}$ \\
\hline Inner beds & $16,100 \mathrm{a}$ & $18,800 \mathrm{a}$ & $20,500 \mathrm{a}$ \\
High beds & $13,233 \mathrm{~b}$ & $16,067 \mathrm{~b}$ & $17,600 \mathrm{~b}$ \\
HSD $(\alpha=0.05)$ & $1,88 \mathrm{I}$ & 2,637 & 2,028 \\
\hline
\end{tabular}

Note The average number followed by the same letter in the same column showed no significant effect on HSD test level $\alpha 0,05$

\section{Leaf length}

The results of variance showed that the interaction of treatment in the direction of the beds and the shape of the beds did not significantly affect the length of the local shallots of Palu, while the shape of the beds had a significant effect on the length and age of $15,25,35$ and 45 DAP.

HSD analysis results $\alpha 0,05$ (Table 2) shows that the shape of beds in producing the highest number of leaves and significantly different from the shape of high beds at the age of 15, 25, 35 and 45 DAP.

Table 2 Average length of leaves age 15, 25, 35 and 45 in the treatment bed shape $(\mathrm{cm})$

\begin{tabular}{lllll}
\hline \multirow{2}{*}{ Bed shape } & \multicolumn{4}{l}{ Age (DAP) } \\
\cline { 2 - 5 } & $\mathbf{1 5}$ & $\mathbf{2 5}$ & $\mathbf{3 5}$ & $\mathbf{4 5}$ \\
\hline Inner beds & $7,143 \mathrm{a}$ & $13,007 \mathrm{a}$ & $15,857 \mathrm{a}$ & $18,313 \mathrm{a}$ \\
High beds & $5,627 \mathrm{~b}$ & $11,203 \mathrm{~b}$ & $13,697 \mathrm{~b}$ & $14,740 \mathrm{~b}$ \\
HSD $(\alpha=0.05)$ & 1,271 & 1,125 & 1,772 & 2006 \\
\hline
\end{tabular}

Note The average number followed by the same letter in the same column shows no significant difference at the HSD test level $\alpha 0,05$

\section{Dried leaf weight per plant}

Results of variance showed that the interaction of treatment in the direction of the beds and the shape of the beds did not significantly affect the dry weight of leaves per local shallot plant in Palu. The shape of the beds significantly affected the dry weight of local shallots in Palu aged 15, 25, 35 and 45 DAP, while the direction of the beds did not significantly affect the dry weight of the leeks at $15,25,35$ and 45 DAP.

The results of the analysis of HSD $\alpha 0,05$ (Table 3 ) shows that the form of beds in generating dry weight of leaves local Palu shallot higher and significantly different from the form of a high embankment at the age of 15,25, 35 and 45 days after planting.

Table 3 Average dry weight leaves per plant Age 15,25,35 and 45 In Treatment Shape Beds $(\mathrm{cm})$

\begin{tabular}{lllll}
\hline \multirow{2}{*}{ Bed Shape } & \multicolumn{4}{l}{ Age (DAP) } \\
\cline { 2 - 5 } & $\mathbf{1 5}$ & $\mathbf{2 5}$ & $\mathbf{3 5}$ & $\mathbf{4 5}$ \\
\hline Inner beds & $0.072 \mathrm{a}$ & $0.157 \mathrm{a}$ & $0.352 \mathrm{a}$ & $0.497 \mathrm{a}$ \\
High beds & $0.045 \mathrm{~b}$ & $0.107 \mathrm{~b}$ & $0.312 \mathrm{~b}$ & $0.388 \mathrm{~b}$ \\
HSD $(\alpha=0.05)$ & 1,271 & 1,125 & 1,772 & 2,006 \\
\hline
\end{tabular}

Note The average number followed by the same letter in the same column shows no significantdifference at the HSD test level $\alpha 0,05$

\section{Total area of leaves per plant}

Variance results showed that the interaction of the treatment of the beds and the shape of the beds did not significantly affect the total leaf area per local shallot plant in Palu. The shape of the beds significantly affected the total leaf area per local shallot plant in Palu aged 15, 25, 35 and 45 DAP, while the direction of the beds did not significantly affect the total area of shallots at 15, 25, 35 and 45 DAP.

The results of the analysis of HSD $\alpha 0,05$ (Table 4) shows that the form of beds in generating total leaf local Palu shallot wider and significantly different from the form of a high embankment at the age of $15,25,35$ and 45 days after planting.

Table 4 Average total area of leaves per plant age 15, 25, 35 and 45 in the bed shape treatment $(\mathrm{cm})$

\begin{tabular}{lllll}
\hline \multirow{2}{*}{ Bed shape } & \multicolumn{4}{l}{ Age (DAP) } \\
\cline { 2 - 5 } & $\mathbf{1 5}$ & $\mathbf{2 5}$ & $\mathbf{3 5}$ & $\mathbf{4 5}$ \\
\hline Inner beds & $20,972 \mathrm{a}$ & $\mathbf{4 4 , 8 7 7 \mathrm { a }}$ & $107,278 \mathrm{a}$ & $151,077 \mathrm{a}$ \\
High beds & $16,720 \mathrm{~b}$ & $35,030 \mathrm{~b}$ & $95,262 \mathrm{~b}$ & $118,442 \mathrm{~b}$ \\
HSD $(\alpha=0.05)$ & 3,884 & 6,643 & 8,118 & 3,684 \\
\hline
\end{tabular}

Note The average number followed by the same letter in the same column shows no significant difference at the HSD test level $\alpha 0,05$

\section{Total dry weight per plant}

The results of variance showed that the interaction of treatment in the direction of the beds and the shape of the beds did not significantly affect the total dry weight per local shallot plant in Palu. The shape of the beds significantly affected the total dry weight per local shallot plant in Palu aged 15 and 45, while those aged 25 and 35 had no significant effect. Likewise, the direction of the beds only significantly affected the total dry weight of plants at 15 DAP, while at 25, 35 and 45 DAP, there was no significant effect. 
HSD $\alpha$ analysis results of 0.05 (Table 5) show that the direction of the beds cutting the slope produces a total dry weight per plant of local Palu red shallots and is significantly different from the sloping beds at the age of 15 DAP.

Table 5 Average total dry weight of treatment direction of beds aged I5 DAP

\begin{tabular}{lll}
\hline Direction of beds & Dry weight $(\mathbf{g})$ & HSD $\alpha \mathbf{0 . 0 5}$ \\
\hline Cut the slope & $0.337 \mathrm{a}$ & 0.06 \\
In the same direction & $0.247 \mathrm{~b}$ & \\
\hline
\end{tabular}

NoteThe average number followed by the same letter in the same column shows no significant difference at the HSD test level $\alpha 0,05$

The results of HSD analysis $\alpha 0.05$ (Table 6) show that the shape of beds in producing total dry weight per plant of local shallots of Palu is greater and significantly different from the shape of beds at ages 15 and 45 DAP.

Table 6 Average total dry weight of local shallot plants in palu age I5 and 45 in treatment of shed forms

\begin{tabular}{lll}
\hline \multirow{2}{*}{ Bed shape } & \multicolumn{2}{l}{ Age (DAP) } \\
\cline { 2 - 3 } & $\mathbf{1 5}$ & $\mathbf{4 5}$ \\
\hline Inner beds & $0.332 \mathrm{a}$ & $\mathrm{I}, 312 \mathrm{a}$ \\
High beds & $0.252 \mathrm{~b}$ & $1,052 \mathrm{~b}$ \\
HSD $(\alpha=0.05)$ & 0.06 & 0.159
\end{tabular}

Note The average number followed by the same letter in the same column shows no significant difference at the HSD test level $\alpha 0,05$

\section{Number of bulbs per clump}

The results of variance showed that the interaction of treatment in the direction of the beds and the shape of the beds did not significantly affect the number of tubers per cluster of local shallots in Palu. Whereas the direction of the beds and the shape of the beds have a significant effect on the number of tubers per cluster of local shallots in Palu.

The results of the analysis of HSD $\alpha 0,05$ (Table 7) shows that the form of beds in generating the number of tubers per clump of red shallot local Palu is a lot and significantly different from the form of beds high.

Table 7 Average total dry weight per plant age 15, 25, 35 and 45 in the bed shape treatment

\begin{tabular}{lll}
\hline Bed shape & $\begin{array}{l}\text { Number of bulbs per clump } \\
\text { (fruit) }\end{array}$ & HSD $\alpha \mathbf{0 . 0 5}$ \\
\hline Inner beds & $9,647 \mathrm{a}$ & 1,278 \\
High beds & $8017 \mathrm{~b}$ & \\
\hline
\end{tabular}

Note The average number followed by the same letter in the same column shows no significant difference at the HSD test level $\alpha 0,05$

\section{Weight of dry harvest bulbs per hectare}

The results of variance showed that the interaction of treatment in the direction of the beds and the shape of the beds did not significantly affect the dry tuber weight of the local shallots of Palu. While the shape of the beds had a significant effect on the weight of dried tubers in Palu's local shallots.
The results of the analysis of HSD $\alpha 0,05$ (Table 8) show that the form of beds in a heavy yield per hectare crop dried tubers local Palu shallot higher and significantly different from the form of beds high.

Table 8 Average number of bulbs per clump on treatment of bed forms

\begin{tabular}{lll}
\hline Bed shape & $\begin{array}{l}\text { Number of bulbs } \\
\text { per clump (fruit) }\end{array}$ & HSD $\alpha \mathbf{0 . 0 5}$ \\
\hline Inner beds & $9,647 \mathrm{a}$ & $\mathrm{I}, 278$ \\
High beds & $8017 \mathrm{~b}$ &
\end{tabular}

Note The average number followed by the same letter in the same column shows no significantdifference at the HSD test level $\alpha 0,05$

\section{Discussion}

Plant growth is the result of interaction between plant factors (genetic) with environmental factors in which the plant grows. One of the environmental factors that has a very important role in the process of metabolism, plant growth and development is water. Thus the availability of water according to the needs of plants in each phase of growth is very important to get attention. Furthermore, the direction of the beds and the shape of the beds are closely related in influencing the availability of the plant growing environment.

The results showed that the interaction between the direction of the beds and the shape of the beds as well as the single factor in the direction of the beds did not significantly affect the growth and yield of Palu's local shallots. This is due to the fact that the two factors that have been tried are not yet in optimal condition to be able to play a role in influencing the growth and development of Palu's local shallots. This is thought to be the availability of water that has not been maximized according to the needs of plants, because these two factors are closely related to the ability of the land to obtain, store and release water for plant growth needs, especially in dry land conditions whose irrigation depends on irrigation water. The direction and shape of the planting beds must be adjusted to the land and climate conditions, especially rainfall, where the shape of the inner beds can serve as a container that can hold water so as to increase the availability of ground water, whereas beds can function to reduce standing water that can damage plants in conditions of high rainfall, Sitanala Arsyat. ${ }^{5}$

Furthermore, the treatment of the shape of the beds gives a real influence on the growth of local shallots in Palu, where the shape of the beds can provide growth in the number of leaves, leaf length, leaf dry weight, total leaf area per plant and total dry weight per plant. The facts in the field illustrate that in the research location which is a dry land, the use of beds in being very effective plays a role in increasing soil water content to continue to be used by plants in their growth. Conversely, in the form of high beds, water relative if less available to plants so that growth is not as good as those planted in deep beds. As stated by Nielson et al. ${ }^{6}$ land management is related to the condition of crop water shortages and better plant growth conditions throughout the growing season. In this case what is important in the management of irrigation water is the frequency of irrigation and the amount of water supplied at each phase of plant growth.

Likewise with the shallot yield component, the treatment of deepbed forms can give results in the form of the number of tubers per clump, dry tuber weight per clump and tuber yield per hectare higher than the higher bed shape. This is in addition to being influenced by the relatively lower water availability in high beds compared to deep beds, because in higher beds requires a relatively greater amount of 
water, time and water pressure to be able to increase soil water content when compared to the shape of deep beds. This relates to what was stated by Winarba. ${ }^{8}$ that the method of irrigation should be determined by the depth of the soil layer soaked in water, horizontal distribution of water and the period of potential water stress, where this is an important factor and has a profound effect on crop production. This shows that water in addition to playing a role in improving the growth of vegetative parts can also increase crop yields. The function of water in the plant is essential, so if water is available in sufficient quantities needed by plants in each phase of growth, the direct will increase the growth rate which in turn will help determine crop yield.

Water in plants acts primarily as raw material for photosynthesis, solvent media and mineral nutrient transport, the main constituent of protoplasms ${ }^{8}$ and uptake efficiency (UE) of N, P and K were significantly improved under precision land leveling with raised bed planting technique compared to other practices. ${ }^{9}$ Furthermore, Levitt ${ }^{10}$ explained that plants in their growth would experience metabolic and physiological disorders due to water stress. ${ }^{11-15}$

\section{Conclusion}

1. There was no significant interaction between the treatment of the beds and the shape of the beds on the growth and yield of Palu's local shallots.

2. In general, the direction of the treatment of beds does not significantly affect the growth and yield of Palu's local shallots.

3. The shape of the inner beds can give growth and yield to the local shallots of Palu better than the shape of the raised beds.

\section{Acknowledgments}

Thank you to the shallots farmers of Guntarano Village for the land that was given for use in this study.

\section{Conflicts of interest}

Authors declare no conflict of interest exists.

\section{References}

1. Rukmana R. Post-harvest cultivation and processing shallots. Kanisius. Yogyakarta. 2000.
2. Wibowo S. Shallot cultivation. self-help spreaders. Jakarta. 2007.

3. Sunaryono H, P Soedomo. Shallot cultivation. CV. Sinar Baru, Bandung. 1983.

4. Central sulawesi agriculture service. Profile of palu local shallots. Sub-din development of processing and marketing of central sulawesi agriculture and livestock services office. Palu. 2005.

5. Sitanala A rsyad. Soil and water conservation. IPB Press. Bogor agricultural institute. Bogor. 2006.

6. DC Nielsen, PW Unger, PR Miller. Efficient water use in dryland cropping systems in the great plains. Agron J. 2002;97(2):364-372 (2005).

7. Winarba S. Effect of groundwater content on growth and production of two types of kapolaga sabrang. Bul Agron. 2000;28(1):1-8.

8. Dwidjosepoetra. Introduction to plant physiology. PT Gramedia Pustaka Utama. 1990.

9. ML Jat, Raj Gupta YS, Saharawat Raj Khosla. Layering precision land leveling and furrow irrigated raised bed planting: productivity and input use efficiency of irrigated bread wheat in indo-gangetic plains. American Journal of Plant Sciences. 2011;2:578-588.

10. Levitt L. Responses of plants to environment stresses. Dep. Of Plant Biology. Carnages Ins. Of Washington Standford, California, MD. 1980.

11. Balitbang Agriculture. Prospects and directions $\mathrm{p}$ development of agribusiness shallot. Agricultural research and development agency. Agriculture department. Jakarta. 2007.

12. Bidwell RGS. Plant physiology. Mc. Millan Publ. Co. C. Cys, E van Ranst, J. Debaveye and F. Beernaert. 1993. Land evaluation. Part III Crop Requirements. Agricultural publications-No 7; General administration for development cooperation. Belgium. 1979.

13. Palu City Agriculture Service. Technical guidelines for the development of palu local shallots agribusiness in 2007. Agriculture, Forestry and Marine Services of the City of Palu. Palu. 2007.

14. Central sulawesi agriculture service. Central Sulawesi Agriculture and Animal Husbandry Service. Palu. 2008.

15. Rahayu E, N Berlian. Shallots. Self-help Spreaders. Jakarta. 2007.h 